\title{
Determination of mothers' depression levels by the type of special educational services they get for their autistic children $^{1}$
}

\author{
Bahar Odabaş Özgür² \\ Mürşit Aksoy ${ }^{3}$ \\ Menşure Aydin ${ }^{4}$ \\ Serkan Koçkaya ${ }^{5}$ \\ Bergün Meriç Bingül ${ }^{6}$
}

\begin{abstract}
The purpose of this study is to determine the depression levels of mothers by the type of special educational services they got for their autistic children. Mothers of 20 male autistics and 5 female autistics participated in the study as volunteers. \%24 of families got educational services from life coaches, $\% 48$ from O.C.E.M (Autistic Children Education Centers) and \%28 from rehabilitation centers. Beck depression scale applied to volunteers to determine the depression levels (SCORES, Life Coach $=16 \pm 7,05$, O.C..E.M $=13,83 \pm 7,05$, Rehabilitation Center $=25,57 \pm 9,28)$. Data were presented as mean, $\mathrm{SD}$, frequency for description purpose. Variables were analyzed and were calculated by using Kruskal Wallis Test and Mann Whitney U tests. There is a significance difference at level of $\mathrm{P}<0.05(\mathrm{p}=0,035)$ between parents which get different types of special educational services. As a result; significant difference has found in the depression levels of parents which get special educational services from rehabilitation centers found more depressive then O.C..E.M and life coach services.
\end{abstract}

Keywords: Mothers’ Depression; Autistic Children; Depression Levels.

\section{Introduction}

The expectation and wish of the whole family, including parents, after they learn mother's pregnancy is to have a healthy child. However, if the child born with disabilities, it results in disappointment, stress and traumas for the rest of the family members. Child with disabilities is seen as the destruction of the ideal child in parents' minds and they suffer in such situation. Suffering is considered as a feeling, indicating the acceptance of the reality.

In today's world, autism is one of these common disabilities that are found in children. By definition, autism is a neuropsychiatric dysfunction, which starts in the earlier periods of life, continues throughout the life and delays or distorts the social relations, communication, and behavioral and cognitive development (Üstüner Top, 2009; Güleç-Aslan et. al., 2009).

\footnotetext{
1 Early version of this study was presented as verbal statement at 9th Annual International Conference: Physical Education Sport and Health, University of Pitesti, Romania, 2016.

2 Assist. Prof. Dr., Kocaeli University, Faculty of Sports Sciences, baharozgur@yahoo.com

3 Assist. Prof. Dr., Kocaeli University, Institute of Health Sciences, mursitaksoy@gmail.com

${ }^{4}$ Assoc. Prof. Dr., Kocaeli University, Faculty of Sports Sciences, mensure@,kocaeli.edu.tr

${ }^{5}$ Std., Kocaeli University, Faculty of Sports Sciences, serkan.kockaya@gmail.com

${ }^{6}$ Assoc. Prof. Dr., Kocaeli University, Faculty of Sports Sciences, bergunm@kocaeli.edu.tr
} 
Odabaș Özgür, B., Aksoy, M., Aydın, M., Koçkaya, S., \& Meriç Bingül, B. (2016). Determination of mothers’ depression levels by the type of special educational services they get for their autistic children. Journal of Human Sciences, 13(3), 6092-6097. doi:10.14687/ihs.v13i3.4269

The families with autistic children have anxiety for being uninformed about what to do with their children or in what way the children will affect their lives. There are some problems due to adaptation of such children, who have very special needs for the most of the time, into family life. All of these anxieties stem from the fear of families against unknown, because none of the children with autism is similar to each other in terms of their autistic properties.

Parents encounter with a series of behavior, which are hard to be defined. Taking care of the needs and wishes of a child, who cannot communicate; trying to maintain the order within the family environment; struggling with different types of behavior patterns in children; and protecting them against dangers cause a considerable amount of stress in the family. Therefore, the anxiety and stress, that the family experiences, leads to depression (Girli, 2005; Üstüner Top, 2009). In general, depression appears at the end of suffering period. Most of the time, parents fall into depression as a result of the belief that they can no longer stand for the responsibilities (Kaytez et. al., 2015; Ergin et. al., 2007).

Supporting families with autistic children in accordance to their needs increases the participation of children in education and may impact the development of child positively (Yildirım et. al., 2012).

One of these institutions; In December 1999, the Ministry of Education promulgated the opening of Autistic Children Education Centers (OÇEM) within the scope of "Autistic Children Education Project" (OÇEP) for the education for children diagnosed with autism. The commission has started to work in 1995 and in May, 1999 "Autistic Children Education Program (3- 15 age group)"has been accepted by M.E.B. (Ministry of Education) Board of Education to contribute to the education of children with autism (Aksüt, 2001).

The inclusive education of children with autism is given in dependent OÇEMs linking to the class that the primary school of child with autism provides according to his/her performance. Whereas in independent OÇEMs, the child who is capable of taking the inclusive education is provided part-time inclusive education in a class of the closest school, which is suitable for his/her performance and age, related to the decision of Special Education Services Board. Independent OÇEM provides supportive education service to the primary school of child with autism during the inclusive education process ("Millî Eğitim Bakanllğı Otistik Çocuklar Eğitim Merkezleri Yönergesi," 2004).

Trainers on child development, special education teachers, psychologists or guidance counselors work in rehabilitation centers for the education of individuals with autism, Individuals with autism are investigated there in terms of language and speech; their physical, mental and social development; and they are evaluated for their development according to their age levels. It also carries on its tasks, which are defined in the sections above, in rehabilitation centers for the education of individuals with autism (T.C. Millî Eğitim Bakanliği, 2014)

In recent years, individuals with autism have started to form sports club associations in order to prepare themselves to life with sports and life programs, to increase awareness and quality of life, to develop skills for independent act and to support cognitive and sensitive development while doing sports. Families with autistic children have begun to use services provided by these clubs in day-time programs or accompanying with a life coach who can take care of children in any time.

The aim of the study is to investigate the effect of educational services, that mothers with autistic children benefit from in order to support their education, on the levels of depression regarding to having children with autism. 
Odabaş Özgür, B., Aksoy, M., Aydın, M., Koçkaya, S., \& Meriç Bingül, B. (2016). Determination of mothers’ depression levels by the type of special educational services they get for their autistic children. Journal of Human Sciences, 13(3), 6092-6097. doi:10.14687/ihs.v13i3.4269

\section{Material \& Method}

The study is composed of a total 25 mothers of 20 males, 5 female children with autism. 6 of these families benefit from life coaches with one-to-one education, 12 from OÇEM (Autistic Children Education Centers), and 7 from rehabilitation centers.

The data are collected with a survey form, which is developed by researchers in order to measure the socio-demographic properties of parents and to determine from which educational institution (Life coach, OÇEM, rehabilitation centers) that they benefit from. Moreover, Beck Depression Inventory (BDI) is used to determine the level of depression for mothers with autistic children via face-to-face interview. BDI is developed by Beck et. Al. (1978) and its validity-reliability study has been conducted in our country by Hisli (Hisli, 1988). BDI contains a list of a total 21 questions and the score interval is between 0 and 63 .

When analyzing the data, percentage and frequency values are used in statistical analysis and measurement of demographic properties; mean scores and standard deviation are used in Beck Depression Inventory analysis; and Kruskal Wallis test is used in comparison between groups. Significance level is taken as $\mathrm{p}<0.05$.

\section{Findings}

Table 1: Gender of Children with Autism in the Research

\begin{tabular}{lcr} 
& Frequency & $\%$ \\
\hline Male & 20 & 80,0 \\
Female & 5 & 20,0 \\
Total & 25 & 100,0 \\
\hline
\end{tabular}

In this research, $80 \%$ of children with autism are males and $20 \%$ are females.

Table 2: The Education Level of Mothers of Children with Autism in the Research

\begin{tabular}{lcr} 
& Frequency & $\%$ \\
\hline Illiterate & 1 & 4,0 \\
Literate & 1 & 4,0 \\
Primary School & 8 & 32,0 \\
Secondary School & 10 & 40,0 \\
University & 5 & 20,0 \\
Total & 25 & 100,0 \\
\hline
\end{tabular}

In general, the education level of mothers is at secondary school level.

Table 3: The Education Level of Fathers of Children with Autism in the Research

\begin{tabular}{lcr}
\hline & Frequency & $\%$ \\
\hline Primary School & 8 & 32.0 \\
Secondary School & 10 & 40,0 \\
University & 7 & 28.0 \\
Total & 25 & 100,0 \\
\hline
\end{tabular}

The education level of fathers is $40 \%$ on the secondary school level. 
Odabaş Özgür, B., Aksoy, M., Aydın, M., Koçkaya, S., \& Meriç Bingül, B. (2016). Determination of mothers’ depression levels by the type of special educational services they get for their autistic children. Journal of Human Sciences, 13(3), 6092-6097. doi:10.14687/jhs.v13i3.4269

Table 4: The Occupation of the Mothers of Children with Autism in the Research

\begin{tabular}{lcr}
\hline & Frequency & $\%$ \\
\hline Housewife & 14 & 56,0 \\
Worker & 5 & 20,0 \\
Officer & 5 & 20,0 \\
Self-Employed & 1 & 4,0 \\
Total & 25 & 100,0 \\
\hline
\end{tabular}

According to the research, 56\% mothers are housewives (unemployed), $20 \%$ of them are working as workers, $20 \%$ are officials and $4 \%$ are self-employed.

Table 5: The Occupation of the Fathers of Children with Autism in the Research

\begin{tabular}{lcr} 
& Frequency & $\%$ \\
\hline Worker & 13 & 52,0 \\
Officer & 5 & 20,0 \\
Self-Employed & 5 & 20,0 \\
Retired & 2 & 8,0 \\
Total & 25 & 100,0 \\
\hline
\end{tabular}

Majority of fathers in the study are workers.

Table 6: The Special Educational services that Children with Autism Get Education

\begin{tabular}{lcr}
\hline & Frequency & $\%$ \\
\hline One-to-one & 6 & 24,0 \\
OÇEM & 12 & 48,0 \\
Rehabilitation & 7 & 28,0 \\
Total & 25 & 100,0 \\
\hline
\end{tabular}

$24 \%$ of the families participated in the research are using one-to-one education, $48 \%$ using OÇEM and \%28 using programs in the rehabilitation centers.

Table7: The Mean Scores and Standard Deviations of Three Groups

\begin{tabular}{lccccc}
\hline & $\mathrm{N}$ & Min. & Max. & Mean & Std. Dev. \\
\hline OÇEM & 12 & 9,00 & 25,00 & 16,6667 & 5,83615 \\
Life Coach & 6 & 7,00 & 25,00 & 13,8333 & 7,05455 \\
OÇEM & 7 & 15,00 & 38,00 & 25,5714 & 9,28901 \\
\hline
\end{tabular}

Table 8: Comparison of Three Educational Institutions (Kruskal-Wallis Test)

\begin{tabular}{|c|c|c|}
\hline & & Test \\
\hline Chi-Square & & 6,694 \\
\hline df & & 2 \\
\hline Asymp. Sig. & & ,035 \\
\hline \multicolumn{3}{|l|}{$* \mathrm{P}<0.05$} \\
\hline \multicolumn{3}{|c|}{ Table 9: The Resultsof Back Depression Tests } \\
\hline Groups & Z & $\mathrm{P}$ \\
\hline OÇEM- One-to-one Education & $-1,083$ & 0,279 \\
\hline OÇEM - Rehabilitation & $-2,118$ & $0,034 *$ \\
\hline One-to-one Education - Rehabilitation & $-2,146$ & $0,032 *$ \\
\hline
\end{tabular}

$* \mathrm{P}<0.05$ 
Odabaș Özgür, B., Aksoy, M., Aydın, M., Koçkaya, S., \& Meriç Bingül, B. (2016). Determination of mothers’ depression levels by the type of special educational services they get for their autistic children. Journal of Human Sciences, 13(3), 6092-6097. doi:10.14687/ihs.v13i3.4269

The parameters OCEM - Rehabilitation and One-to-one Education - Rehabilitation showed significant differences $(\mathrm{p}<0.05)$.

\section{Discussion}

Evaluation of the problems and state of minds of families with autistic child: It has been concluded as a result of qualitative analysis that it is hard for parents to accept when their child are diagnosed with autism; their modes of living change greatly; they isolate themselves from their environment; become more emotional; feel anxious for the future; give up most of the things that they want to do; after all, they feel happy when they take care of their children and there are great changes in their life perspectives (Üstüner Top, 2009).

It has been observed that the $20 \%$ of children of participants of our study was female and $80 \%$ is male. Autism is more common in boys than girls. In a study conducted in US, it has been found that the ratio between girls and boys varies across states; for each girl diagnosed with autism spectrum disorder, the ratio of boys changes between 3.4 and 6.5. These findings have shown that prevalence in boys is 4-5 times more than the prevalence in girls (T.C. Sağlık Bakanllğı Tohum Otizm Vakfi, 2008)

The education level of most of the families participated in the research is secondary school $(40 \%)$, and in terms of occupation, $56 \%$ of mothers are housewives and $52 \%$ of fathers are workers. The relatives of people with disabilities predominantly belong to middle-low level income class, $70 \%$ of households are composed of 6 or more members, $63 \%$ of households have only one person as the breadwinner. In this respect, it has been observed that the relatives of people with disabilities have generally economic distress. When the distribution of occupation among employed people is investigated, $36 \%$ appeared as workers, $10 \%$ as officials, and $5 \%$ as craftsmen. 4 out of 10 individuals with disabilities are appeared as unemployed (Yumuşak M., Çelikel Ş., Üçdăg M., \& Yildırım S., 2014)

In her study on the depression levels of parents, Softa (Softa, 2013) has asserted that parents' depression mean scores are medium level with $21.600 \pm 10.722$. A similar study on the depression levels of families with disabled members has shown that families have series levels of depression (39.98 \pm 10.71) (Dereli \& Okur, 2008). As a result of studies investigating the depression level of parents with disabled children and determining the factors behind this, total BDE mean score is found as low level (13.44 \pm 9.51) (Engin et. Al., 2007).

According to Beck Anxiety Scale points, which has been used in a study on the anxiety, depression and stress levels of mothers of children with mental or physical disabilities, the scores are higher than the control group (Uğuz, Toros, İnanç, \& Çolakkadıoğlu, 2004). In our study, it has also been found that mothers with autistic children are in depression. Particularly, depression levels are much greater in groups who benefit from rehabilitation centers.

The comparison between groups showed significant differences between OÇEM Rehabilitation Centers and between One-to-one - Rehabilitation Centers $(p<0.05)$. The lowest scores for depression were appeared in one-to-one education group. The reason for this result can be considered as children's possibility to spend time with life coaches, to do sports and calming effect of sports creates opportunity for parents to spend more time for themselves. The highest depression scores were observed in groups using rehabilitation centers. The children going to rehabilitation centers are going there with certain sessions and the families may need to spend more time with children. In the educational institutions of OÇEM, there are day-long activities, specifically on exercise and drama. When the families find a place for their children where they can be taken care of all day, they feel more relaxed. 
Odabaș Özgür, B., Aksoy, M., Aydın, M., Koçkaya, S., \& Meriç Bingül, B. (2016). Determination of mothers’ depression levels by the type of special educational services they get for their autistic children. Journal of Human Sciences, 13(3), 6092-6097. doi:10.14687/ihs.v13i3.4269

\section{Results and Suggestions}

In this research, $80 \%$ of children with autism are males and $20 \%$ are females. The education level of familic educational services. The comparison between groups showed significant differences between OÇEM - Rehabilitation Centers and between One-to-one - Rehabilitation Centers $(p<0.05)$. More groups could be added in the study. Other parameters can be considered families can be exposed to consciousness raising sessions

\section{References}

Aksüt M. (2001)"Yeni Bin Yılın Yeni Eğitim Merkezleri (OÇEM’ler) ve Otistik Bireylerin Eğitimi AKÜ Sosyal Bilimler DergisiVol III. No 2, pp. 56-71

Dereli, F., \& Okur, S. (2008). Determination of the depression level of the families having a handicapped child. New Medical Journal, 25, 164-168.

Ergin D, Şen N, Eryllmaz N, Pekuslu S, Kayacı M (2007). Engelli Çocuğa Sahip Ebeveynlerin Depresyon Düzeyi ve Etkileyen Faktörlerin Belirlenmesi, Atatürk Üniversitesi Hemşirelik Yüksekokulu Dergisi, 10: 1

Girli A. (2006). Otistik Çocukların Ailelelerine Yönelik Grup Rehberlik Programının Anne Babaların Depresyon ve Kayg1 Düzeylerine Etkisi. I. Uluslararası İzmir Özel Eğitim ve Otizm Sempozyumu, sunulmuş bildiri, Balçova/İzmir.

Güleç-Aslan Y., Kırcaali-İftar G., Uzuner Y., (2009).Otistik Çocuklar İçin Davranışsal Eğitim Programı (OÇIDEP) Ev Uygulamasının Bir Çocukla İncelenmesi , Ankara Üniversitesi Ĕgitim Bilimleri Fakültesi Özel Eğitim Dergisi. 10 (1) 1-25

Hisli, N. (1988). A study on the validity of Beck Depression Inventory. Turkish Journal of Psychology, 6(22), 118-123.

Kaytez N., Durualp E., Kadan G. (2015), Engelli Çocuğu Olan Ailelerin Gereksinimlerinin ve Stres Düzeylerinin İncelenmesi, Journal of Research in Education and Teaching Vol:4 No: 1

Softa, H. K. (2013). Engelli Çocuğa Sahip Ebeveynlerin Depresyon Düzeylerinin Incelenmesi. Kastamonu Eğitim Dergisi, 21(2).

T.C. Millî Eğitim Bakanlı̆̆ Otistik Çocuklar Eğitim Merkezleri Yönergesi. (2004). Retrieved May 15, 2016, from http://mevzuat.meb.gov.tr/html/2567 0.html

T.C. Millî Eğitim Bakanliği. (2014). Özel eğitim kurumlarında fiziksel özellikler ve personel. Ankara.

T.C. Sağlık Bakanlığı Tohum Otizm Vakfi. (2008). Otizm Tarama Projesi Sonuç Raporu. İstanbul.

Uğuz, Ş., Toros, F., İnanç, B. Y., \& Çolakkadıŏlu, O. (2004). Zihinsel ve/veya bedensel engelli çocukların annelerinin anksiyete, depresyon ve stres düzeylerinin belirlenmesi. Klinik Psikiyatri, 7(1), 42-7.

Üstüner Top F (2009). Otistik Çocuğa Sahip AilelerinYaşadıkları Sorunlarile Ruhsal Durumlarının Değerlendirilmesi: Niteliksel Araştırma Fadime * ÇocukDergisi 9(1):34-42

Yıldırım A, Hacıhasanoğlu Aşılar R, Karakurt P (2012), Determination of Psychological Status of Motherswith Disabled Children, İ.Ü.F.N. Hem. Derg. Vol 20 - No 3: 200-209

Yumuşak M., Çelikel Ş., Üçdağ M., \& Yıldırım S. (2014). Şanlıurfa'da Engelli Bireylerin Ve Ailelerinin Toplumsal Hayatta Yaşadıkları Zorlukların Araştırılması Projesi Araştirma Raporu. Şanlıurfa: Karacadağ Kalkınma Ajansı. 